

\title{
GOLDILOCKS AND THE SAN FRANCISCO ESTUARY: HOW SCIENTISTS DETERMINE WHEN WATER IS "JUST RIGHT"
}

\section{Morgan N. Martinez * and Theodore M. Flynn *}

Division of Integrated Science and Engineering, California Department of Water Resources, West Sacramento, CA, United States

YOUNG REVIEWERS:

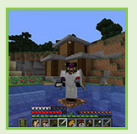

DAVID

AGE: 10

a VARDHAN SINGHAL

AGE: 10

Have you ever accidentally gotten seawater in your mouth? You probably spit it out because it tasted so bad, right? Even though it looks clear, water in rivers, bays, and oceans contains lots of other things besides $\mathrm{H}_{2} \mathrm{O}$, including some things that are not healthy for people or animals! To determine the quality of a body of water, scientists measure the temperature and how much salt, sediment, and nutrients are present in that water. Too much or too little of these things, caused by pollution, floods, or droughts, might be bad for the health of the environment. Just like the porridge in the story of Goldilocks and the Three Bears, water quality must be "just right" to be healthy for the living things that need it.

\section{WHAT MAKES WATER "JUST RIGHT"}

There is much more to water than what meets the eye. While it may look clear to us, there are many things found in water that we cannot 


\section{WATER QUALITY}

A measure of how suitable a body of water is for a specific use.

\section{TURBIDITY}

A measure of how cloudy the water is, usually caused by floating particles.

\section{ESTUARY}

A water passage where the salt water from the ocean meets the freshwater from a river.

\section{Figure 1}

The delta smelt, an endangered fish, native to the San Francisco Estuary, that is impacted by changes in water quality. see, such as salt, sediment, oxygen, and nutrients. All these things together characterize how healthy or unhealthy the water is. Scientists call the health of the water water quality. Estuaries are important ecosystems where freshwater from high up in the mountains meets the salty water from the ocean. The water in estuaries is critically important for people, plants, and animals because it provides a place to live, the relief of a cool drink, and tasty food to eat. Unlike lakes or ponds, water in estuaries is in constant motion, sloshing back and forth due to tides, gravity, and rain. As a result, the water quality is always changing too. Scientists who study estuaries must therefore constantly monitor the water quality to make sure it is healthy for the creatures that live there.

How do we know if water quality is healthy or unhealthy? In the story of Goldilocks and the Three Bears, a little girl named Goldilocks explores the house of the three bears while they are away. After trying out each bear's furniture and food, Goldilocks discovers that she does not like porridge that is scalding hot or ice cold, or beds that are rock hard or pillow soft. Instead, she prefers things between these two extremes, where it is "juuuuust right." Like Goldilocks, all living things need balance in their environments to thrive. In the remainder of this article, we will explain three components of water quality that are often closely monitored by scientists: turbidity, temperature, and nutrients.

\section{TURBIDITY}

Let us look more closely at one component of water quality, called turbidity. Turbidity is a measure of how cloudy the water is. High turbidity can occur when a lot of water is flowing through the estuary,




Figure 2

A research boat navigating the waterways of the San Francisco Estuary.

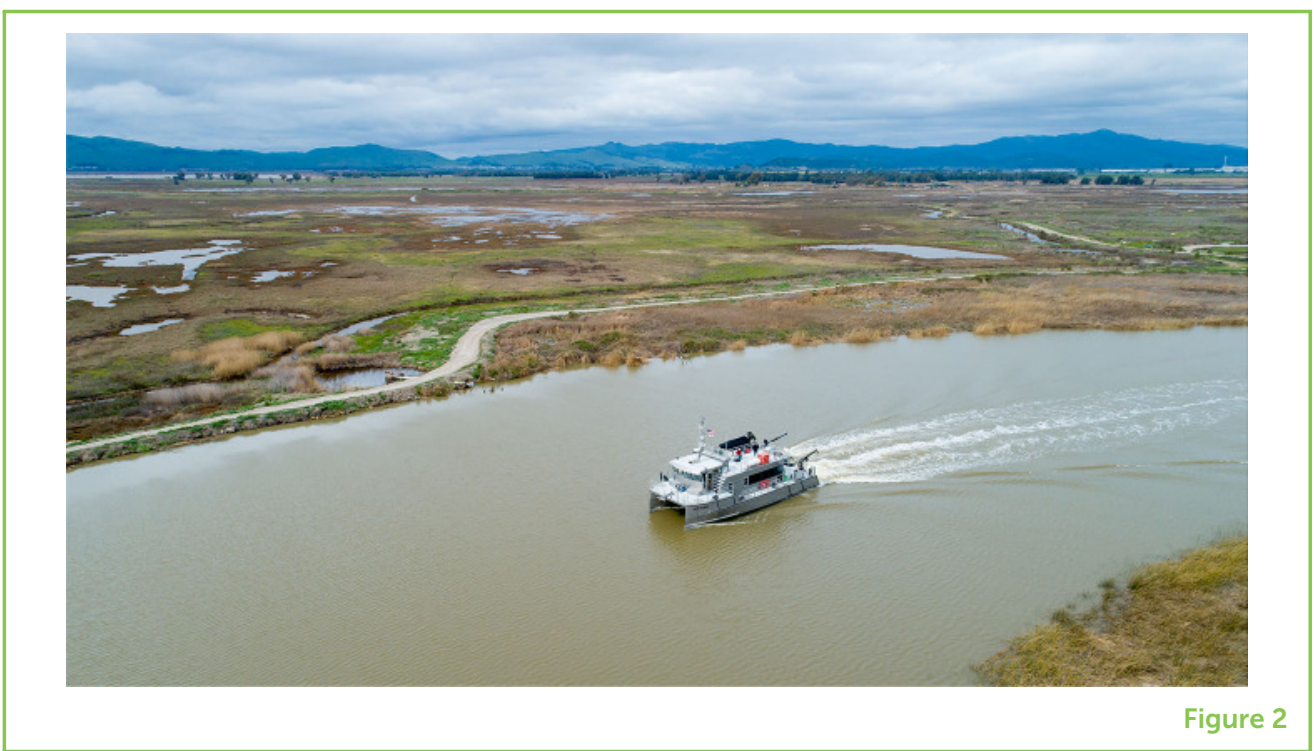

disturbing the sediment on the bottom, and scattering it throughout the water. This makes the water appear cloudy. On the other hand, low turbidity occurs when there is not a lot of sediment or other material floating through the water column, and you can usually see straight to the bottom because it is so clear. But which is better for fish and other creatures living in an estuary: low turbidity or high turbidity?

The answer is a bit complicated, but it helps to think about it from the point of view of the fish. Let us consider a very important fish friend, the delta smelt (Figure 1). This small, transparent fish is native to California's San Francisco Estuary (Figure 2). Scientists have discovered that turbid (cloudy) water is a critical feature of its habitat [1]. This is probably because delta smelt are small, so turbid water helps them hide from big predators that want to eat them. For a predator fish like the striped bass, however, turbid water makes finding things to eat (like the delta smelt) more difficult. From the perspective of the smelt, high turbidity is helpful. On the contrary, high turbidity might be detrimental to the survival of the striped bass. Just like the three bears preferred different porridges and beds (food and habitat) various animals in the estuary prefer different types of conditions. Managing an ecosystem as complex as an estuary requires scientists to balance many competing needs.

\section{TEMPERATURE}

Anyone who has ever taken a relaxing shower or bath knows that warm water can feel great. For people, a warm bath can be the perfect way to relax after a stressful day. While soaking in warm water may make us calm and happy, for some fish in estuaries it is just the opposite: warm water stresses them out! Small, natural changes in water temperature are being made worse by global processes like climate change, and 


\section{WASTEWATER}

Water that has been used and contaminated by humans and must be treated and cleaned before it can be returned safely to the environment.

\section{PHYTOPLANKTON}

Very small organisms that create food from sunlight using photosynthesis. These organisms are an important part of the food web in estuaries and many other environments.

\section{ALGAL BLOOM}

Quickly growing microscopic algae that often results in colorful scum on the surface of the water.

\section{MICROCYSTIN}

A toxic chemical created by very small organisms called phytoplankton. Microcystin is harmful to fish, people, and other creatures.

1 See The Frontiers for Young Minds article "Are You a HAB Warrior?" for more information: https://kids.frontiersin org/articles/10.3389/ frym.2021.611282.

\section{HYPOXIA}

A condition that occurs when the amount of oxygen dissolved in water becomes too low for fish to breathe through their gills. Hypoxia often happens because of pollution. this is putting fish like the delta smelt in jeopardy. In the past 10 years, we have experienced many of the hottest years on record. These scorching temperatures do not just make those of us on land sweat and look for relief in the shade, they change the behavior of fish too!

Warmer water causes some species of fish to change habitats, to find cooler places to live. A recent study found that just a few degrees change in temperature, from 17 to $21^{\circ} \mathrm{C}$, was enough to change how delta smelt swim and makes them easier for predators to catch and eat [2]. Warmer water can also increase the risk that fish like salmon will get certain diseases. To help keep water temperatures in the San Francisco Estuary cool in the sweltering summer weather, scientists and officials often release colder water from behind dams, to keep the rivers at a safe temperature for fish.

\section{NUTRIENTS}

If you have ever looked at the back of a vitamin bottle, you know that we need to eat many different nutrients to stay healthy! Animals and plants also need a balanced diet with plenty of nutrients. For creatures that live in the water, two of the most important nutrients are nitrogen $(\mathrm{N})$ and phosphorus $(\mathrm{P})$. Keeping these nutrients in balance is extremely important. Where do the nutrients in the water come from? In places like the San Francisco Estuary, nutrients in the water mainly come from human activities! When fertilizer (which contains lots of nutrients like $\mathrm{N}$ and $\mathrm{P}$ ) is applied to lawns or to crops on a farm, not all of it is used by the grass or plants. When it rains, some of those nutrients wash away and enter the water system, eventually ending up in rivers, estuaries, and bays. Wastewater, which enters the water system via sewers, is also high in $\mathrm{N}$ and $\mathrm{P}$.

The proper amount of nutrients in the water is important to help plants (and the animals who eat those plants) to grow, but there can be too much of a good thing! An excess of nutrients in the water can cause some very tiny plants, called phytoplankton, to quickly grow to high numbers. This is called an algal bloom [3]. While phytoplankton are a very important part of an estuary's food web, a dense bloom of phytoplankton can be harmful, because some produce toxic chemicals called microcystins, which make the water unsafe for drinking or swimming (Figure 3$)^{1}$. Making things even worse, when the nutrients in the water are used up, the phytoplankton die and are consumed by bacteria that deplete the oxygen in the water, resulting in a condition called hypoxia. Fish need to breathe oxygen with their gills, so when water becomes hypoxic, large numbers of fish can die. Unfortunately, the warming water temperatures caused by climate change often make harmful algal blooms worse. 
Figure 3

A harmful algal bloom caused by overgrowth of Microcystis algae in the San Francisco Estuary.

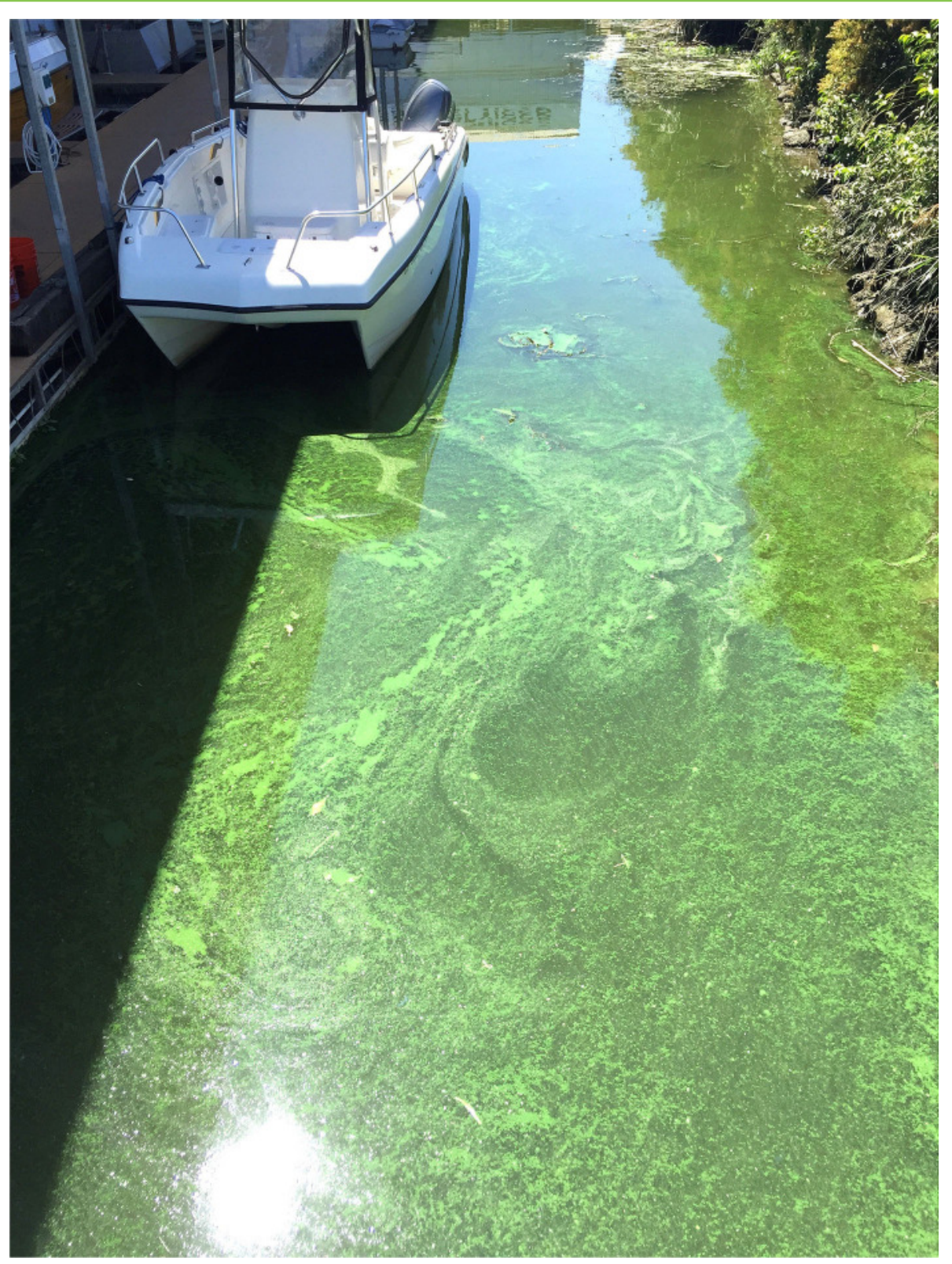

Figure 3

\section{HEALTHY WATER, HEALTHY ORGANISMS}

As you can see, water quality is made up of many different components. Most creatures (including people) need those components to be in balance so that they can stay healthy. Managing that balance can be challenging for scientists. As we have learned, it is possible to have too much of a good thing. While turbidity, temperature, and nutrients all have an impact on water quality, extremes of any of these factors, whether too much or too little, can be detrimental to the creatures that live in aquatic ecosystems. So, the next time you take a trip to a river, lake, or even the ocean, take a closer look at the water and remember that everything that makes the water "just right" is just beyond what your eyes can see. 


\section{REFERENCES}

1. Feyrer, F., Nobriga, M. L., and Sommer, T. R. 2007. Multidecadal trends for three declining fish species: habitat patterns and mechanisms in the San Francisco estuary, California, USA. Can. J. Fish. Aquat. Sci. 64:723-34. doi: 10.1139/f07-048

2. Davis, B. E., Hansen, M. J., Cocherell, D. E., Nguyen, T. X., Sommer, T., Baxter, R. D., et al. 2019. Consequences of temperature and temperature variability on swimming activity, group structure, and predation of endangered delta smelt. Freshw. Biol. 64:2156-75. doi: 10.1111/fwb.13403

3. Ohte, N., Dahlgren, R. A., Silva, S. R., Kendall, C., Kratzer, C. R., and Doctor, D. H. 2007. Sources and transport of algae and nutrients in a Californian river in a semi-arid climate. Freshw. Biol. 52:2476-93. doi: 10.1111/j.1365-2427.200 7.01849.x

SUBMITTED: 15 October 2020; ACCEPTED: 02 July 2021; PUBLISHED ONLINE: 03 August 2021.

EDITED BY: Dominik K. Großkinsky, Austrian Institute of Technology (AIT), Austria

CITATION: Martinez MN and Flynn TM (2021) Goldilocks And The San Francisco Estuary: How Scientists Determine When Water Is "Just Right". Front. Young Minds 9:612572. doi: 10.3389/frym.2021.612572

CONFLICT OF INTEREST: The authors declare that the research was conducted in the absence of any commercial or financial relationships that could be construed as a potential conflict of interest.

COPYRIGHT @ 2021 Martinez and Flynn. This is an open-access article distributed under the terms of the Creative Commons Attribution License (CC BY). The use, distribution or reproduction in other forums is permitted, provided the original author(s) and the copyright owner(s) are credited and that the original publication in this journal is cited, in accordance with accepted academic practice. No use, distribution or reproduction is permitted which does not comply with these terms.

\section{YOUNG REVIEWERS}

\section{DAVID, AGE: 10}

I am David and I like to carve things and build. I like constructing furniture and I like to write letters. I am 10 and I am in grade 5 .

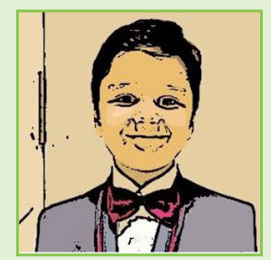

\section{VARDHAN SINGHAL, AGE: 10}

My name is Vardhan and I am 10 years old. I enjoy cricket and reading books on outer space. My favorite subjects are Math and English. 

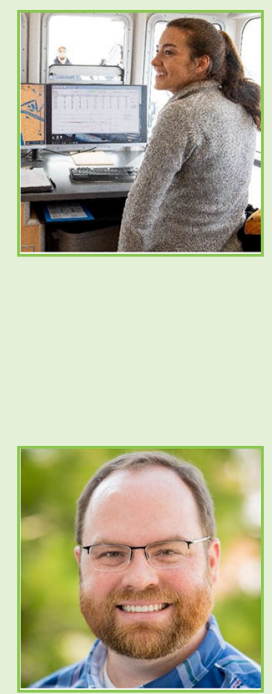

\section{AUTHORS}

\section{MORGAN N. MARTINEZ}

I am an environmental scientist for California's Department of Water Resources in the Division of Environmental Services. I received my degree in biological sciences with a concentration in ecology, evolution, and conservation from California State University, Sacramento. My work is focused on monitoring the water quality and aquatic organisms that live in the San Francisco Estuary and I have spent many field days navigating through these waters aboard a 60-foot research vessel. *morgan.martinez@water.ca.gov

\section{THEODORE M. FLYNN}

I am a senior environmental scientist in the state of California's Department of Water Resources. I lead the discrete unit of the Environmental Monitoring Program, which has been collecting and analyzing water and biological samples in the San Francisco Estuary for over 40 years. I study the connection between water quality and biological communities in different aquatic environments, including the San Francisco Estuary. I received a Ph.D. in geology from the University of Illinois at Urbana-Champaign and a B.S. in environmental geoscience from the University of Notre Dame. In my free time, I enjoy riding bicycles, reading books, watching movies, and traveling. *theodore.flynn@ awater.ca.gov 